\title{
Family Support With Self-Care Ability In Mental Retardation Children In SLB State 1 Bulukumba
}

\author{
Tenriwati ${ }^{*}$, Haerani2, Rahmi Islamiah ${ }^{3}$ \\ Departemen of Child and Maternity Nursing , Stikes Panrita Husada Bulukumba, Indonesia ${ }^{1}$ \\ Departemen of Child and Maternity Nursing, Stikes Panrita Husada Bulukumba ,Indonesia ${ }^{2}$ \\ S1 Nursing Study Program, Stikes Panrita Husada Bulukumba, Indonesia ${ }^{3}$
}

Corresponding Autor : tenriwatisalala@gmail.com*

\begin{abstract}
Mental retardation is a lack of intelligence. Children with mental retardation in addition to having limited intelligence are also limited in their ability to care for themselves so that they need support from their families. From the results of the study conducted by researchers on June 25, 2018, on 30 respondents, who received support supported by the family of 21 respondents and who received less support as many as 9 respondents. while self-care ability, which is capable of 20 respondents who can self-care and 10 poor respondents in self-care. This study aims to determine the relationship of family support with the ability of self-care in children's Mental Retardation in Bulukumba 1 Public Middle School in 2018. The research method uses an analytical design with a "cross-sectional" approach. The population in this study is 42 people. The sample of this study as many as 30 respondents showed family support in the criteria supporting 21 respondents and those who did not support 9 respondents with the purposive sampling method. The results of the analysis of the relationship between family support with the ability of self-care in children's Mental Retardation in Bulukumba 1 Public Middle School in 2018, with Fisher's alternative chi-square statistical test, with a level of confidence $(\alpha=0.05)$. Based on the test results obtained values $(p=0,000)$ then Ho is rejected and Ha accepted. The conclusion of this study is, "The Relationship of Family Support with SelfCare Ability in Children Mental Retardation in Bulukumba 1 Public Middle School in 2018 It is suggested to families, especially parents to more support and guide children with mental retardation to achieve good self-care abilities.
\end{abstract}

Keywords: Support Families, Self-Care

\section{INTRODUCTION}

Mental retardation or mental retardation is a disorder in which general intellectual functioning is below average. Those who are mentally retarded cannot take care of themselves according to their age (Apriyanto, 2012). According to (Word Health Organization, 2017) reports mental disorders (disability) show between 35\% and 50\% in developed countries. Whereas in developing countries $76 \%$ and $85 \%$. Whereas the number of children with special needs, mentally retarded children ranks second after 


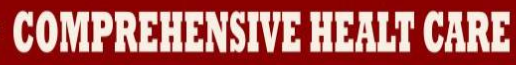

children with mental retardation with the number of children experiencing mental retardation (30,460 children) of the total population of Indonesia (82,840,600 children) Data (Riskesdas, 2013) South Sulawesi is the highest population experiencing mental retardation (23.8\%), Central Sulawesi (19.6\%), West Sulawesi (13.4\%), and the lowest in West Papua (4,6\%), Banten (5.1\%) DKI Jakarta (7.7\%), and Riau (8.5\%) including children over 15 years of age.

Those who experience mental disabilities experience difficulties or functional limitations in carrying out daily activities and taking care of themselves such as cleaning the body, and difficulty in wearing clothes (Situation of persons with disabilities, 2014). This is evidenced by the results of interviews with the deputy head of SLB Negeri 1 Bulukumba said SLB students and other school students are very different in terms of cleanliness. SLB students have limited abilities and are very dependent on the surrounding environment, especially children who experience mental retardation. Based on direct observation of SLB Negeri 1 Bulukumba students in terms of personal hygiene is very poor in terms of messy clothes, dirty nails, and messy hair. This is due to lack of attention and support from parents towards their children (SLB Negeri 1).

Based on the results of research conducted by Zemmy Arfandi, Eko Susilo and Gipta Galih Wododo (2013) in SLB Negeri Unggran, the results were obtained with the title Social Family Support with the ability to self-care in children with mental retardation. In line with research conducted by Oktavia Alfita Sari and Wesiana Heris Santy in (2017) at SLB Tunas Mulya Sememi Village, Benowo District, showed that the Relationship of Family Support with the level of independence of children's personal hygiene is a factor that is related to the independence of Tunagrahita personal hygiene. The purpose of this study is to find out whether there is a relationship between family support and self-care ability in mental reterdation children in SLB Negeri 1 Bulukumba.

\section{MATERIAL AND METHODS}

The research design used in this study is analytic design with Cross Sectional approach (Dharma, 2013). which aims to determine the relationship of Family Support with Self-Care Ability in Children Mental Reterdasi in SLB Negeri 1 Bulukumba. Population is a unit where a research result will be applied (Kusuma Dharma, 2013). The population in this study were all students who experienced mental retardation in SLB Negeri 1 Bulukumba as many as 42 students, mild mental retardation as many as 22 


\section{COMPRABHENSWE HABH CARE}

and students who experienced moderate mental retardation as many as 20 students and families living in the same house.

The sampling technique in this research is non-probability sampling. Nonprobability sampling with a purposive sampling approach. Purposive Sampling is a sample selection method that is based on the specific goals and objectives determined by the researcher by using a categorical two unpaired groups. The instrument used in the study used a questionnaire with a Likert scale approach. Calcalertic was used to measure the attitudes, opinions, perceptions of a person about symptoms or problems in their nature example if the statement was positive Never with a value of 1 , sometimes with a value of 2 , often with a value of 3 and always with a value of 4 and if never with a value of 4, Sometimes with a value of 3, Often with a value of 2 and Always 1 (Hidayat, 2014). Research instruments (questionnaire) must meet the requirements of valid and reliable (Dharma, 2013). After the data is processed into an expected (precise and consistent) data then it is analyzed (1) Univariate Analysis functions to summarize the data set of measurement results in such a way that the data set of measurement results. In this analysis in the form of tebel, and graphs.

In this study, frequency distribution regarding the characteristics of family support and self-care ability will be known. (2) Bivariate analysis serves to determine the relationship between variables. Bivariate analysis in this study is to determine the relationship of family support with self-care ability in children with mental retardation. This analysis uses the chi-square test and if the data are not normal then use the test (fisher) frequency distribution observed with the expected degree of significance 0.05. If P-Value $<0.05$ means there is a significant relationship (Ho is rejected) while P-Value $>$ 0.05 means there is no meaningful relationship (Ho is accepted) (Sujarweni, 2014)

\section{RESULTS}

Table 1 Distribution of Family Frequencies by Characteristics

\begin{tabular}{lcc}
\hline Characteristics Respondent & n & Percentage (\%) \\
\hline Gender & & \\
Male & 14 & 46.7 \\
Female & 16 & 53.3 \\
Age & & \\
Early Adolescents (19-29) & 6 & 20.0 \\
Late adulthood (30-39 & 14 & 46.7 \\
Early Elderly ( $\geq 40)$ & 10 & 33.3 \\
Level Of Education & & \\
No school & 5 & 16.7
\end{tabular}




\section{COMPREHENSWE HEHW CARE}

\begin{tabular}{lcc} 
Basic & 5 & 16.7 \\
Middle & 8 & 26.7 \\
High & 9 & 30.0 \\
Bachelor & 2 & 6.7 \\
Diploma & 1 & 3.3 \\
Profession & & \\
Housewife & 17 & 56.7 \\
Employee & 2 & 6.7 \\
Entrepreneur & 3 & 10.0 \\
Farmers & 1 & 3.3 \\
Driver & 3 & 10.0 \\
There is no & 3 & 10.0 \\
College student & 1 & 3.3 \\
Family relationship & & \\
Mother & 14 & 46.7 \\
Father & 12 & 40.0 \\
Brother & 4 & 13.0 \\
\hline Amount & $\mathbf{3 0}$ & $\mathbf{1 0 0 , 0}$
\end{tabular}

Based on (Table 1) shows that most of the sexes are male 18 respondents $(60.0 \%)$ most of the age (7-12 years) as many as 24 respondents (80.0\%) mostly elementary school education 24 Respondents (80.0\%). Shows most of the sexes are female 16 respondents (53.3\%) most of the late adult age (30-39) 14 (46.7\%) most of the high school education 9 respondents (30.0\%) partial The level of work was 17 respondents IRT (56.7\%) and most of the family relations were 17 respondents mother (46.7).

Table 2 Frequency Distribution of Number of Respondents Based on Support from families with self-care ability.

\begin{tabular}{lcc}
\hline Family support & $\mathbf{n}$ & Percentage(\%) \\
\hline Support & 21 & $70 \%$ \\
Not Supporting & 9 & $30 \%$ \\
\hline Careability Self & & \\
\hline Able & 20 & $66.7 \%$ \\
Less fortunate & 10 & $33.3 \%$ \\
\hline Amount & $\mathbf{3 0}$ & $\mathbf{1 0 0 . 0}$
\end{tabular}

Based on (Table 2) shows the distribution of the number of respondents based on family support with self-care ability. Family support of respondents Most family support supports 21 respondents (70\%) while less supports the level of 9 respondents (30\%). The ability of self-care most able to 20 respondents (66.7) while less able 10 (33.3).

Table 3. Relationship between Family Support and Self-Care Ability

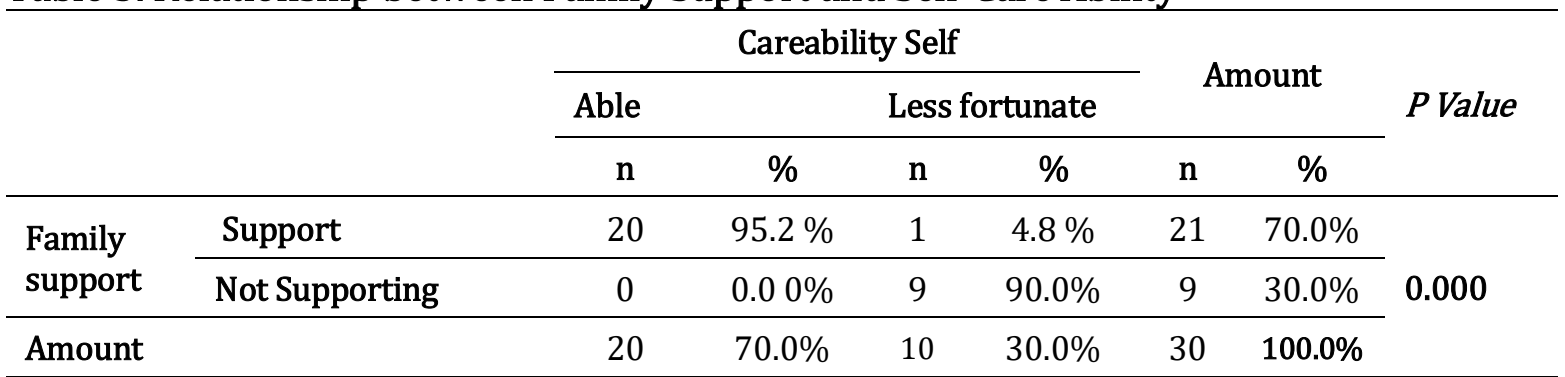




\section{COMPRABHENSWE HEAH CARE}

Based on (Table 5) shows the relationship of family support with self-care ability where the category of support supported by the family there are 21 respondents (70.0\%) and who are able to perform self-care as many as 20 respondents (95.2\%) higher than the support and less able to do self-care 1 respondent (4.8\%). Whereas the less supportive there are 9 respondents (30\%) and those who are able to perform selfcare there are 0 respondents $(0.0 \%$ lower than the less supportive and less capable there are 9 respondents (90.0) Chi-Squared test results obtained p =0,000 (a $<0.05$ ), but there is 1 cell (25\%) then it is not fulfilled so using alternative fisher, it is concluded that there is a relationship between family support and self-care ability in children with mental retardation in SLB Negeri 1 Bulukumba.

\section{DISCUSSION}

Research shows there is a relationship between family support and self-care ability in SLB Negeri 1 Bulukumba. where it is proven that family support can help someone more eager in carrying out activities and goals desired, especially from those closest to the family in order to grow love, be respected and loved (Widyanto, 2014). So family support is the relationship between families to appreciate each other for their success and the provision of a family atmosphere that reflects that each individual is accepted, supported and cared for (Harmoko, 2012). From the results of the study (Rima \& Dwijaya, 2015) Chi Suare test obtained $p$ value $=0.001(p<0.05)$, it can be concluded that there is a significant relationship between parenting patterns with self-care ability in mentally retarded children in SDLB C. This is in line with the results of the study (Ramawati, Allenidekania, \& Besral, 2012). It is found that there is a relationship between parental warfare and self-care ability based on internal and external factors with a value of $p=0.005$. Based on the results of the study (Mbuinga, 2015) using the Chi Suare test $\mathrm{p}$ value $=0.012(\mathrm{p}<0.05)$, it can be concluded that there is a significant relationship between family support with the independence of Activity Daily Living (ADL) in retardation in the district of pohuwanto. This is in line with the research carried out (Arfandi, Susilo, \& Widodo, there is a relationship between family social support and self-care ability in mental retardation children in SLB Negeri Unggaran with Chi Square test with $\mathrm{p}$ value $=0.004$.

Based on the results of the study (Sari \& Santy, 2017) using the Chi Suare test obtained $\mathrm{p}=0.030(\mathrm{p},<0.05)$, it can be concluded that there is a significant relationship between family support with the level of independence of personal hygiene and mental 


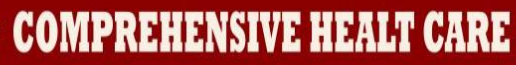

retardation in SLB shoots mulya sememi village, benowo sub-district. This is in line with research conducted by (Mayungsari \& Astrani, 2013) there is a moderate relationship between family support and social interaction in children with moderate mental retardation with a value of $p=0,000$. Researchers assume in family support that the family becomes the first environment in providing encouragement or support in the form of knowledge to children. In family support must be met both informational support, emotional support, instrumental support and appreciation support because the existence of this support will make children able to achieve what they want one of them is capable of self-care.

And as for self-care in children with mental retardation according to (Apriyanto, 2012) The ability of body maintenance, bathing, brushing teeth, treating hair, nail hygiene. This is proven based on the results of research conducted by (Wardani, Azza, \& Komaruddin, 2015) with the support of the family will make mental retardation children will be independent, but if the lack of attention given to retarded children will experience limitations in various midwives one of them self-care such as bathing, decorating, eating, and toileting in the intellectual sebakannya very lacking. The results of the above study are in line with research conducted by (Panjaitan \& Karnasih, 2011) the relationship between parenting and self-care abilities of mental retardation children at the elementary level in SLB Bhakti Kencana II with Yogyakarta with cross sectional approach with a population of 35 students and 35 the parents of these students with a sampling technique using total sampling. The statistical test results obtained $\mathrm{p}$ value $=$ 0.039 so that it can be concluded the relationship between the pattern of the parent's home and the self-care ability of children with mental retardation at the elementary level in SLB Bhakti kencana II with Yogyakarta. With the support of the family will make the child mentally retarded to be independent, but if the lack of attention given to the retarded child will experience limitations in a variety of midwives, one of them self-care such as bathing, decorating, eating, and toileting in the intellectual as it is very less.

The results of the above research are in line with the results of research conducted by (Wardani, Suriadi, \& Faui, 2015) the relationship of the role of parents with the independence of children with mental retardation in SLarma Dharma Asih Pontianak using Chi Square test with a value of $p=0,000$. the role of parents is very influential with independence in children who experience mental retardation children because children who experience mental retardation children in which intellectual functions 


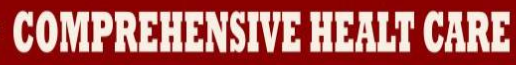

have limited abilities. This research is carried out (Nurmani, 2014) the relationship between parenting style and personal hygiene ability in children with mental retardation in SDLB in jamber district there is a significant relationship with the value of $\mathrm{p}=0.03$ foster patterns applied in the family system will have a positive effect on child. Researchers assume that the ability of self-care depends on each family support given to children. So parental warfare is very important to guide and direct children to be able to take care of themselves. the more children age, the war the parents have to do especially during their daily fulfillment so that later they do not have continuous dependence.

\section{CONCLUSIONS}

Based on the results of the study above, it was concluded that there was a significant relationship between family support and self-care ability in children with mental retardation in SLB Negeri 1 Bulukumba. For families, especially parents in order to increase the support given to their children, especially children who have mental retardation.

\section{REFERENCES}

Apriyanto, N. (2012). Seluk Beluk Tunagrahita \& Strategi pembelajarannya. Jogjakarta: Javalitera.

Arfandi, Z., Susilo, E., \& Widodo, G. G. (2016). hubungan antara dukungan sosial keluarga dengan kemampuan perawatan diri pada anak retardasi mental di SLB Negeri unggran.

Dharma, K. K. (2013). Metodologi penelitian keperawatan. Jakarta: TIM.

Harmoko. (2012). Asuhan keperawatan keluarga. Yogyakarta: Pustaka Belajar.

Hidayat, A. A. (2014). Metode penelitian keperawatan tekhnik analisis data. Jakarta: Salemba medika.

Mayungsari, M. D., \& Astrani, K. (2013). Dukungan keluarga meningkatkan interaksi sosial anak dengan retardasi mental sedang. jurnal stikes.

Mbuinga, E. (2015). Hubungan dukungan keluarga dengan tingkat kemandirian Activity Daily Living (ADL) pada Tunagrahita di kabupaten pohuwato. Jurnal Keperawatan.

Nurmani, R. D. (2014). Hubungan pola asuh orang tua dengan kemampuan perawatan personal hygiene pada anak retardasi mental di SDLB kabpaten jamber.

Panjaitan, F. S., \& Karnasih, W. (2011). Hubungan pola asuh orang tua dengan kemampuan perawatan diri anak retardasi mental di SLB Bhakti kencana II berbah yogyakarta. 


\section{COMPRABHENSWE HEAH CARE}

R. N., \& Dwijaya, R. (2015). Hubungan pola asuh orang tua dengan kemampuan perawatan diri pada anak Tunagrahita di SDLB C Budi Nurani di wilyah puskesmas Baros kota sukabumi.

Ramawati, D., Allenidekania, \& Besral. (2012). Kemampuan perawatan diri pada anak tunagrahita bersarkan faktor eksternal dan internal anak. Jurnal keperawatan indonesia.

Riskesdas. (2013). pravelensi penduduk indonesia yag mengalami disabilitas.

Sari, O. A., \& Santy, W. H. (2017). Hubungan dukungan keluarga dengan tingkat kemandirian personal hygiene anak tunagrahita di SLB Tunas Mulya Kelurahan Sememi Kecematan Benowo. Jurnal ilmiah kesehatan vol. 10, No.2.

Sujarweni, V. W. (2014). Metodologi penelitian keperawatan. Yogyakarta.

Wardani, H. R., Azza, A., \& Komaruddin. (2015). pengaruh terapi generalis defisit perawatan diri terhadap kemandirian perawatan diri anak retardasi mental diSLB C TPA kabupaten jamber. jurnal keperawatan fikes.

Wardani, N. S., Suriadi, \& Faui, M. (2015). Hubungan peran orang tua dengan kemandirian anak retardasi mental di SLBN dharma asih pontianak. Jurnal Kepeerawatan dan kesehatan, Volume, No 2.

Word Health Organiation. (2017). population of children who experience child mental retardation worldwide. 